законодавства України. Юридичний часопис Національної академії внутрішніх справ. 2020. № 2 (20). C. 21-32. DOI: https://doi.org/ $10.33270 / 04202002.21$.

4. Проект нового Кримінального кодексу України станом на 02.01.2021p. URL: https://newcriminalcode.org.ua/upload/media/2021/ 01/04 /kontrolnyj-proekt-kk-02-01-2021.pdf.

5. Про запобігання корупції: Закон України від 14.10.2014 p. № 1700-VII. Відомості Верховної Ради Украӥни. 2014. № 49. Ст. 205.

6. Хавронюк М. І. Науково-практичний коментар до закону України «Про засади запобігання і протидії корупції». К. : Атіка, 2011. С. 472.

7. Концептуальні засади нової редакції Кримінального кодексу України : матеріали міжнар. наук. конф., м. Харків, 17-19 жовт. 2019 р. / редкол. : В. Я. Тацій (голов. ред.), А. П. Гетьман, Ю. В. Баулін та ін. Харків : Право, 2019. 500 с.

DOI https://doi.org/10.30525/978-9934-26-179-4-39

\title{
ОКРЕМІ ПИТАННЯ КВАЛІФІКАЦІЇ НЕЗАКОННОЇ ПОРУБКИ АБО НЕЗАКОННОГО ПЕРЕВЕЗЕННЯ, ЗБЕРІГАННЯ, ЗБУТ ЛІСУ ЗА СУКУПНІСТЮ ЗЛОЧИНІВ ІЗ НАСТУПНИМ ПРИВЛАСНЕННЯМ ЗРУБЛЕНИХ В ЛІСІ ДЕРЕВ
}

\author{
Конопельський В. Я. \\ доктор юридичних наук, професор, \\ завідувач кафедри кримінального права та кримінологї \\ Одеський державний університет внутрішніх справ \\ м. Одеса, Україна \\ Будяченко О. М. \\ кандидат юридичних наук, \\ дочент кафедри кримінального права та кримінології \\ Одеський державний університет внутрішніх справ \\ м. Одеса, Україна
}

Досі залишається одним із дискусійних питань у науковій площині та проблемою застосування на практиці можливість кваліфікації за сукупністю злочинів незаконну порубку або незаконне перевезення, зберігання, збут лісу із наступним привласненням зрублених в лісі дерев. 
Аналіз правозастосовної практики свідчить про наявність неоднозначних та суперечливих випадків кваліфікації діянь незаконної порубки з наступним заволодінням лісом за сукупністю злочинів. Як приклад, у лютому 2019 року було відкрито кримінальне провадження за ч. 3 ст. 185 та ст. 246 Кримінального кодексу України (далі - ККУ) [1] за фактом незаконної порубки мешканцями Новомосковського району Дніпропетровської області дуба на території урочища «Товсте» [2]. Однак 3 огляду на формування судової позиції кваліфікація окреслених дій повинна бути здійснена виключно за ст. 246 КК України і тільки у випадку заволодіння лісом, який зрубаний іншими особами, дії правопорушників можуть кваліфікуватись як крадіжка [3].

На наш погляд така сформована практика $є$ очевидною $з$ огляду на постанови пленуму Верховного суду України від 10 грудня 2004 р. «Про судову практику у справах про злочини та інші правопорушення проти довкілля», де в п. 9 відзначено, що заволодіння деревами, зрубаними та підготовленими до складування або вивезення, залежно від обставин справи слід кваліфікувати за відповідними частинами ст. 185 КК України або іншими статтями, якими передбачено відповідальність за вчинення злочинів проти власності [4].

Як зазначає О. В. Скворцова в подібних випадках мова йде не про ліс як об’єкт природи, а про товарну продукцію - деревину, вилучену $з$ довкілля шляхом докладання праці. Причому особа усвідомлює, що такі предмети вже «вибули» 3 довкілля за допомогою докладання до них праці, а також мають певну вартість і $є$ майном [5, с. 170].

Серед вчених-юристів $\epsilon$ різні думки 3 питання розмежування природного ресурсу і категорії товару, а саме моменту, коли природний ресурс набуває статус майна.

Незаконна порубка або незаконне перевезення, зберігання, збут лісу в дійсності може в подальшому перерости в розкрадання, зокрема в крадіжку, за умови того, що після вчинення злочинних діянь передбачених ст. 246 КК України, деревина була виявлена співробітниками лісового господарства, було проведено обрахунок обсягу, проставлені таврування тощо. На професійній мові співробітників лісництва, це має назву секвестрування деревини, тобто встановлення на балансові рахунки підприємства. Так от якщо деревина була секвестрована, то після цього вона набуває іншого статусу, переходить в категорію товарно-матеріальних цінностей, і має власника в особі лісового господарства, і якщо після цього, деревина, навіть залишена на місці лісової ділянки, але оприбуткована співробітниками лісового господарства, була викрадена, то вчинене слід кваліфікувати ні що інше, як крадіжка (ст. 185 КК України). 
До речі, в цій ситуації варто погодитись із думкою Л. Д. Демидовою, яка обгрунтовуючи можливість кваліфікації посягань на довкілля за сукупністю злочинів, зазначає, що природні ресурси можуть бути предметом злочинів як проти довкілля, так і проти власності залежно від їх:

1) введення в цивільно-правовий або (та) економічний обіг без відокремлення від екосистеми (наприклад, земельна ділянка чи ліс передається у власність фізичної особи, але ця земля чи ліс залишаються складовою екосистеми);

2) належності до екосистеми без введення в обіг [6, с. 270].

В якості рекомендацій для роботи правоохоронних органів, слід зазначити, що у випадках коли незаконна порубка лісу не була виявлена співробітниками лісового господарства, а деревина не була секвестрована, говорити про крадіжку буде помилково, так як умовний власник (хоча і незаконний), не змінився, а подальші дії які направлені на легалізацію деревини, шляхом здійснення продажу, дарування, обміну на інше майно, оплаті наданих послуг чи виконання робіт можуть кваліфікуватись додатково за ст. 198 КК України (придбання, отримання, зберігання чи збут майна, одержаного злочинним шляхом).

При цьому 3 об'єктивної сторони дії, які вчиняються під час вивезення деревини, самі по собі не створюють окремого складу злочину, а лише $\epsilon$ частиною незаконної порубки або незаконного перевезення, зберігання, збуту лісу. Таким чином, на наш погляд, при вчиненні злочину передбаченого ст. 246 КК України немає підстав додатково кваліфікувати дії за ст. 185 КК України у випадку вивезення деревини, яка не була поставлена на баланс лісового господарства.

\section{Література:}

1. Кримінальний кодекс України від 5 квіт. 2001 р. Верховна Рада України. URL: http://zakon3.rada.gov.ua/laws/show/2341-14.

2. Хищение древесины занесенного в Красную книгу дуба на 2 млн гривен блокировано в Днепропетровской области. CENSOR. 2019. URL: https://censor.net.ua/p3113340 (дата звернення: 17.12.2019).

3. Вирок Чернігівського районного суду Чернігівської області від 19 червня 2018 р., судова справа № 748/2800/17. URL: http://reyestr.court. gov.ua/Review/74768778 (дата звернення: 17.12.2019).

4. Про судову практику у справах про злочини та інші правопорушення проти довкілля : постанова Пленуму Верховного Суду України від 10 груд. 2004 р. Верховна Рада Украӥни. URL: http://zakon5.rada.gov.ua/laws/show/ v0017700-04. 
5. Скворцова О. В. Кримінально-правова характеристика незаконної порубки лісу за кримінальним законодавством України (на підставі матеріалів практики автономної республіки Крим): дис. ... канд. юрид. наук: 12.00.08. Сімферополь, 2007. 218 с.

6. Демидова Л. М. Проблеми кримінально-правової відповідальності за заподіяння майнової шкоди в Україні (майнова шкода як злочинний наслідок): теорія, закон, практика: монографія. Харків: Право, 2013. $752 \mathrm{c}$.

\title{
DOI https://doi.org/10.30525/978-9934-26-179-4-40
}

\section{ПОНЯТТЯ ЛАТЕНТНОЇ ЗЛОЧИННОСТІ ТА ШЛЯХИ ЇЇ ПОДОЛАННЯ}

\author{
Макаренко Н. А. \\ студентка V курсу \\ Інститут прокуратури та кримінальної юстиції \\ Науковий керівник: Ткачова О. В. \\ кандидат юридичних наук, \\ дочент кафедри кримінології та кримінально-виконавчого права \\ Національний юридичний університет імені Ярослава Мудрого \\ м. Харків, Украӥна
}

Досліджуючи питання злочинності, завжди треба пам'ятати про такий iii фактор як латентність. Незважаючи на численні спроби іiі зменшення, як шляхом наукових досліджень 3 метою розроблення нових методик подолання, змінами в законодавстві, так і практичними заходами правоохоронних органів, питання латентної злочинності на сьогодні залишається актуальним.

Латентна злочинність (від лат. nãvgро̃ - прихований, невидимий) частина злочинності, яка з різних причин не знаходить відображення у державному обліку вчинених злочинів і осіб, які їх вчинили [3].

Важливим статистичним показником в кримінологічній науці $\epsilon$ рівень злочинності, проте за умови існування іiі у латентній формі видається складним оцінити іiі стан в цілому. Тому маємо ситуацію, коли офіційна статистика не відображає реальності: як в окремих регіонах, так і в державі в цілому. До того ж, латентна злочинність зменшує ступінь достовірності прогнозів щодо розвитку злочинності, підриває авторитет правоохоронних органів, перешкоджає реалізації принципу невідворотності відповідальності. 